Олійничук $\mathrm{P}$.

Особливості розслідування забруднення атмосферного повітря

DOI:

УДК 343.34

\title{
Роман Олійничук,
}

кандидат юридичних наук, дочент кафедри кримінального права та процесу юридичного факультету Тернопільського національного економічного університету

ORCID: http://orcid.org/0000-0003-4228-1384

\section{ОСОБЛИВОСТІ РОЗСЛІДУВАННЯ ЗАБРУДНЕННЯ АТМОСФЕРНОГО ПОВІТРЯ}

Розглянуто забруднення атмосферного повітря як злочин проти довкілля. Проаналізовано погляди науковців на категорії, які стосуються розслідування цьього правопорушення. Обтрунтовано важливість правильного планування дій службових осіб правоохоронних органів для успішного розкриття злочинів проти довкілля, вчинених шляхом забруднення атмосферного повітря. Ідентифіковано особливості окремих слідчих дій під час розслідування забруднення атмосферного повітря та зроблено відповідні авторські висновки.

Ключові слова: атмосферне повітря, злочин, забруднення атмосферного повітря, розслідування забруднення атмосферного повітря, розслідування злочинів проти довкілля, вчинених иляхом забруднення атмосферного повітря.

Олийнычук $\boldsymbol{P}$.

Особенности расследования загрязнения атмосферного воздуха

Рассмотрено загрязнение атмосферного воздуха как преступление против окружающей среды. Проанализированы взгляды ученых на категории, которые касаются расследования данного правонарушения. Обоснована важность правильного планирования действий должностных лич правоохранительньх органов для успешного раскрытия преступлений против окружающей среды, совершенных путем загрязнения атмосферного воздуха. Идентифицированы особенности отдельных следственных действий при расследовании загрязнения атмосферного воздуха и сделаны соответствующие авторские выводы.

Ключевые слова: атмосферный воздух, преступление, загрязнение атмосферного воздуха, расследование загрязнения атмосферного воздуха, расследования преступлений против окружающей среды, совершенных путем загрязнения атмосферного воздуха.

Oliynychuk $R$.

Features of investigation of atmospheric air pollution

Atmospheric air pollution as a crime against the environment is considered. Researchers 'views on the categories related to the investigation of this offense are analyzed. The importance of proper planning of actions of law enforcement officials for the successful detection of crimes against the environment committed by air pollution is substantiated. The peculiarities of individual investigative actions in the investigation of air pollution are identified and the relevant author's conclusions are made.

Keywords: atmospheric air, crime, air pollution, investigation of air pollution, investigation of crimes against the environment committed by air pollution.

Постановка проблеми. Одним з основних життєво важливих елементів навколишнього середовища $є$ атмосферне повітря. Стан атмосферного повітря в Україні, яке є дуже забруднене, завжди викликає велике занепокоєння, оскільки завдає шкоди різним живим системам.

Забруднення атмосфери спричиняє екологічні проблеми, а саме:

- забруднення повітря та зміна його складу внаслідок промислових та інших викидів у атмосферу;

- скорочення чисельності рослинного і тваринного світу та зміни в його генофонді;

- зменшення біологічної продуктивності ландшафтів;

- погіршення умов життєдіяльності людини та інших живих організмів.

В Україні значна частка забруднення атмосферного повітря припадає на стаціонарні джерела викидів. Застаріле обладнання та технології промислових підприємств зумовлюють викиди у катастрофічних обсягах. Щороку по всій Україні в атмосферу виділяється дуже велика кількість шкідливих речовин. Згідно

() Роман Олійничук, 2020 
Кримінальне право та кримінологія. Кримінально-виконавче право. Кримінальний процес та криміналістика. Судова експертиза. Оперативно-розшукова діяльність. Судоустрій. Прокуратура та адвокатура.

з даними Всесвітньої організації охорони здоров’я забруднення повітря є основним екологічним чинником збільшення захворюваності та смертності в світі. За цим показником вже не один рік лідирує Україна.

Відносини у сфері охорони атмосферного повітря становлять об’єкт злочину, передбаченого ст. 241 Кримінального кодексу (КК) України «Забруднення атмосферного повітря» [1], що є одним із злочинів проти довкілля. Тактика та методика розслідування саме таких злочинів в Україні розроблена недостатньо, тому значна кількість цих злочинів залишається нерозкритими, а особи, які їх вчинили, успішно уникають покарання.

Водночас практика досудового розслідування свідчить про наявність певних проблем, а деколи й допущення помилок під час розслідування злочину, передбаченого ст. 241 КК України. Удосконалення та реальних змін потребує також законодавство, що регулює процес досудового розслідування цього тяжкого та небезпечного злочину. Саме це свідчить про актуальність дослідження, яке пов'язане із виявленням особливостей розслідування забруднення атмосферного повітря з метою їхнього врахування у правоохоронній діяльності.

Аналіз останніх досліджень і публікацій. Окремі проблемні аспекти розслідування забруднення атмосферного повітря розглянуто в поацях українських вчених, зокрема Л. Л. Стасюка, О. В. Синчука, В. В. Лаврищев, О. В. Ринкова та ін. Так, наукова робота Л. Л. Стасюка присвячена організації та проведенню огляду місця події під час розслідування злочинів проти довкілля, вчинених шляхом забруднення атмосферного повітря [2]. В іншій науковій праці науковець приділив увагу можливостям судових експертиз у процесі розслідування злочинів проти довкілля, вчинених шляхом забруднення атмосферного повітря [3]. О. В. Синчук розглянув типові версії в методиці розслідування підпалів [4]. У своєму науковому дослідженні В. В. Лаврищев приділив увагу особливостям розслідування екологічних злочинів [5]. О. В. Ринкова обстоює необхідність комплексного підходу до використання спеціальних знань та проведення судово-експертних досліджень під час розслідування екологічних злочинів [6].

Однак, незважаючи на значні наукові здобутки у цьому напрямі, багато аспектів вказаної проблематики, зокрема питання розслідування забруднення атмосферного повітря, все ще малодосліджені та спірні, особливо у їхньому практичному застосуванні.

У зв’язку з цим метою дослідження є виявлення особливостей розслідування забруднення атмосферного повітря з метою їхнього врахування у правоохоронній діяльності.

Виклад основного матеріалу дослідження. Стаття 13 Конституції України вказує на те, що земля, iї надра, атмосферне повітря, водні та інші природні ресурси, які знаходяться в межах території України, природні ресурси іiі континентального шельфу, виключної (морської) економічної зони є об'єктами права власності Українського народу. Від імені Українського народу права власника здійснюють органи державної влади та органи місцевого самоврядування в межах, визначених Конституцією. Кожний громадянин має право користуватися природними об'єктами права власності народу відповідно до закону. Власність зобов'язує. Власність не повинна використовуватися на шкоду людині і суспільства. Держава забезпечує захист прав усіх суб’єктів права власності і господарювання, соціальну спрямованість економіки. Усі суб'єкти права власності рівні перед законом [7].

Конституція України у ст. 16 («Забезпечення екологічної безпеки і підтримання екологічної рівноваги на території України, подолання наслідків Чорнобильської катастрофи - катастрофи планетарного масштабу, збереження генофонду Українського народу є обов'язком держави») передбачає захист екологічної безпеки [7].

А відповідно до статті 50 Конституції України кожен має право на безпечне для життя і здоров’я довкілля та на відшкодування завданої порушенням цього права шкоди. Кожному гарантується право вільного доступу до інформації про стан довкілля, про якість харчових продуктів і предметів побуту, а також право на ії поширення. Така інформація має бути засекречена [7].

Успішне розкриття злочинів проти довкілля, вчинених шляхом забруднення атмосферного повітря, часто залежить від правильного планування дій службових осіб правоохоронних органів на початковому етапі розслідування, оскільки оперативні та кваліфіковані дії саме на цьому етапі дають можливість встановити наявність наслідків злочинних порушень і зафіксувати сліди злочину. Але для повного, всебічного й об’ єктивного розслідування цього злочину необхідно встановити важливі обставини шляхом провадження різних слідчих дій, тактичних операцій.

Однією з найважливіших слідчих дій для збирання доказів під час розкриття злочинів проти довкілля, вчинених шляхом забруднення атмосферного повітря, є огляд місця події. На наш погляд, варто погодитись із Л. Л. Стасюком, що огляд місця події під чам розслідування зазначених злочинів проводиться 
Олійничук Р.

Особливості розслідування забруднення атмосферного повітря

негайно, що обумовлено складністю тривалий час зберегти обстановку місця події в незмінному виді в умовах виробничої діяльності підприємств і можливих змін погоди і особливо складно у випадках, коли джерело забруднення перебуває на значній, іноді на десятки кілометрів, відстані від місця виявлення наслідків такого забруднення. Негайно проведений огляд місця події дає змогу не тільки виявити та зафіксувати матеріальні сліди злочину проти довкілля, вчиненого шляхом забруднення атмосферного повітря, а й усвідомити ситуацію правопорушення, механізм і масштаб негативних наслідків. Отримана в процесі такого огляду криміналістично значима інформація може бути використана для висування слідчих та експертних версій, правильногл оцінювання показань потерпілого, свідка, обвинувачуваного, а також під час призначення різних видів судових експертиз [2].

На думку Л. Л. Стасюка, до особливостей місця події по справах про забруднення атмосферного повітря варто віднести: множинність об'єктів огляду й видів забруднювальних речовин, значні розміри забруднених територій, різноманітність негативних наслідків вчиненого злочину [2].

Розслідування злочинів проти довкілля, вчинених шляхом забруднення атмосферного повітря, вимагає застосування спеціальних знань з різних наукових галузей, оскільки коло об'єктів дослідження у зазначених справах дуже широке. Тому в процесі розслідування цього виду злочину доводиться призначати різні експертизи, в результаті яких можна одержувати відповіді на певні запитання.

Варто зазначити відносно невеликий перелік типових питань, які вирішуються за допомогою судово-експертних досліджень. До них насамперед належать встановлення вмісту, складу шкідливих речовин в атмосферному повітрі, яке згідно з наявними даними піддалося негативному впливу з боку певного господарського об’єкта, концентрації цих речовин, відповідності їх гранично допустимому рівню концентрації. Якщо негативні наслідки такого впливу очевидні, експертиза дає змогу встановити причини події, у тому числі причини захворювання або загибелі рослин, тварин, людей.

Судова експертиза є найбільш ефективним засобом виконання слідчих завдань у справах про злочини проти довкілля загалом та забруднення атмосферного повітря зокрема, за умови неухильного дотримання вимог кримінально-процесуального законодавства щодо призначення та проведення цієї слідчої діï. Експертизу у справах про забруднення атмосферного повітря доцільно призначати тільки тоді, коли в цьому є дійсна необхідність, коли без відповіді експерта на певні питання неможливо встановити істину в справі. До типових експертиз, які призначаються в ході розслідування злочинів проти довкілля, що вчиняються шляхом забрудненням атмосферного повітря, варто віднести: судово-хімічну, токсикологічну, радіологічну, технічну, технологічну, будівельно-технічну, агротехнічну, лісотехнічну, зоотехнічну, гідрометеорологічну, судово-медичну, медико-санітарну, судово-ветеринарну та екологічну експертизи [3].

Серед вищезазначених видів судових експертиз центральне місце займає судово-екологічна експертиза, оскільки вона є комплексним дослідженням, що здійснюють спеціалісти у галузі екології разом 3 медиками, експертами-біологами, зоотехніками, ветеринарами, хіміками, гідрологами, агротехніками, інженерами з очисних споруд, технологами виробництв, пов'язаних із шкідливими відходами, тощо.

У процесі розслідування досліджуваного злочину велике значення має огляд документів щодо правил охорони навколишнього середовища, для чого необхідно знати їхню номенклатуру. Документи можуть бути оглянуті за місцем їхнього знаходження. У випадку, коли необхідно ретельно їх вивчити та зівставити дані, що в них містяться, вони мають бути вилучені шляхом виїмки.

Також під час розслідування злочинів проти довкілля, вчинених шляхом забруднення атмосферного повітря, важливе значення має допит, проведений тактично правильно. Незалежно від особи, яку допитують, ця слідча дія має бути спрямована на встановлення факту забруднення атмосферного повітря, причин та обставин такого забруднення, його наслідків, осіб, які відповідають за дотримання правил охорони довкілля, ступеня їхньої вини, можливості відвернути забруднення та його наслідки.

У ході заключної стадії розслідування забруднення атмосферного повітря доцільно здійснювати важливі тактичні операці0 задля встановлення обставин, що мають важливе значення для справ цієї категоpiï. До них можна віднести: з'ясування функцій службових осіб і технічного персоналу, причинних зв'язків між їхньою діяльністю і наслідками, що настали; визначення фізичної, матеріальної та моральної шкоди, заподіяної забрудненням атмосферного повітря; встановлення причин і умов, що сприяли вчиненню цьогл злочину.

Отже, у результаті проведених досліджень можна зробити висновок про характерні особливості розслідування забруднення атмосферного повітря. По-перше, для цього виду злочинних посягань на довкілля притаманний високий рівень латентності, а це зумовлює необхідність застосування специфічних тактик і методик для їхнього оперативного розслідування. По-друге, надзвичайно важливим елементом 
Кримінальне право та кримінологія. Кримінально-виконавче право. Кримінальний процес та криміналістика. Судова експертиза. Оперативно-розшукова діяльність. Судоустрій. Прокуратура та адвокатура.

розслідування забруднення атмосферного повітря є проведення відповідної судової експертизи, що є найбільш ефективним засобом виконання слідчих завдань у справах про злочини, що пов’язані із забрудненням атмосферного повітря, за умови неухильного дотримання вимог кримінально-процесуального законодавства щодо призначення та проведення цієї слідчої дії. По-третє, дослідження документів, пов’язаних зі справою, вивчення та зіставлення їхніх даних дає змогу сформувати достатню доказову базу. По-четверте, тактично правильно проведений допит осіб, причетних до справи, дає можливість з'ясувати весь спектр причин та обставин заподіяного забруднення, а також встановити осіб, які відповідають за дотримання правил охорони довкілля, визначити ступінь вини кожної з них, можливості відвернення забруднення та його наслідки.

\section{Список використаних джерел}

1. Кримінальний кодекс України : станом на 03.06.2020 / Верховна Рада України. URL : https://zakon.rada. gov.ua/laws/main/2341-14 (дата звернення: 04.06.2020).

2. Стасюк Л. Л. Організація та проведення огляду місця події при розслідуванні злочинів проти довкілля, вчинених шляхом забруднення атмосферного повітря. Форум права. 2011. № 4. С. 711-715.

3. Стасюк Л. Л. Можливості судових експертиз при розслідуванні злочинів проти довкілля, вчинених шляхом забруднення атмосферного повітря. Право і суспільство. Сер. : Кримінально-процесуальне право та криміналістика. 2012. № 1. С. 281-287.

4. Синчук О. В. Типові версії в методиці розслідування підпалів. Наукові дослідження. Сер. : Питання боротьби зі злочинністю. 2015. Вип. 30. С. 116-120.

5. Лаврищев В. В. Особливості розслідування екологічних злочинів. Актуальні проблеми сучасного розвитку міжнародного морського, транспортного та екологічного права. 2010. С. 113-119.

6. Ринкова О. В. Необхідність комплексного підходу до використання спеціальних знань та проведення судово-експертних досліджень під час розслідування екологічних злочинів. Криміналістичний вісник. 2010. № 2 (14). С. 81-87.

7. Конституція України : станом на 21.02. 2019 р. / Верховна Рада України. URL : https://zakon.rada.gov. ua/laws/show/254\%D0\%BA/96-\%D0\%B2\%D1\%80 (дата звернення: 04.06.2020).

\section{References}

1. Kryminalnyi kodeks Ukrainy [Criminal Code of Ukraine]: stanom na 03.06.2020 / Verkhovna Rada Ukrainy. Retrieved from https://zakon.rada.gov.ua/laws/main/2341-14 [in Ukrainian].

2. Stasyuk, L.L. (2011). Orhanizatsiya ta provedennya ohlyadu mistsya podiyi pry rozsliduvanni zlochyniv proty dovkillya, vchynenykh shlyakhom zabrudnennya atmosfernoho povitrya [Organization and inspection of the scene during the investigation of crimes against the environment committed by air pollution]. Forum prava - Law Forum, 4, 711-715 [in Ukrainian].

3. Stasyuk, L.L. (2012). Mozhlyvosti sudovykh ekspertyz pry rozsliduvanni zlochyniv proty dovkillya, vchynenykh shlyakhom zabrudnennya atmosfernoho povitrya [Possibilities of forensic examinations in the investigation of crimes against the environment committed by air pollution]. Pravo $i$ suspilstvo. Ser. Kryminalno-protsesualne pravo ta kryminalistyka - Law and society. Ser. Criminal procedure law and criminology, 1, 281-287 [in Ukrainian].

4. Synchuk, O.V. (2015). Typovi versiyi v metodytsi rozsliduvannya pidpaliv [Typical versions in the method of arson investigation]. Naukovi doslidzhennya. Ser. Pytannya borotby zi zlochynnistyu-Scientific research. Ser. Issues of combating crime, 30, 116-120 [in Ukrainian].

5. Lavryshchev, V.V. (2010). Osoblyvosti rozsliduvannya ekolohichnykh zlochyniv [Features of investigation of ecological crimes]. Aktualni problemy suchasnoho rozvytku mizhnarodnoho morskoho, transportnoho ta ekolohichnoho prava - Current issues of modern development of international maritime, transport and environmental law, 113-119 [in Ukrainian].

6. Rynkova, O.V. (2010). Neobkhidnist kompleksnoho pidkhodu do vykorystannya spetsial'nykh znan ta provedennya sudovo-ekspertnykh doslidzhen pid chas rozsliduvannya ekolohichnykh zlochyniv [The need for a comprehensive approach to the use of special knowledge and forensic research in the investigation of environmental crimes]. Kryminalistychnyy visnyk - Forensic Bulletin, 2 (14), 81-87 [in Ukrainian].

7. Konstytutsiya Ukrayiny [Constitution of Ukraine]. (n.d.). zakon.rada.gov.ua. Retrieved from https://zakon. rada.gov.ua/laws/show/254к/96-вp [in Ukrainian].

Стаття надійшла до редакції 08.06.2020. 